\title{
Masterprogram i \\ selvmordsforebyggende arbeid
}

Marianne Slette Granum intervjues av Ina Bekkevold og Anita Kjølsrud

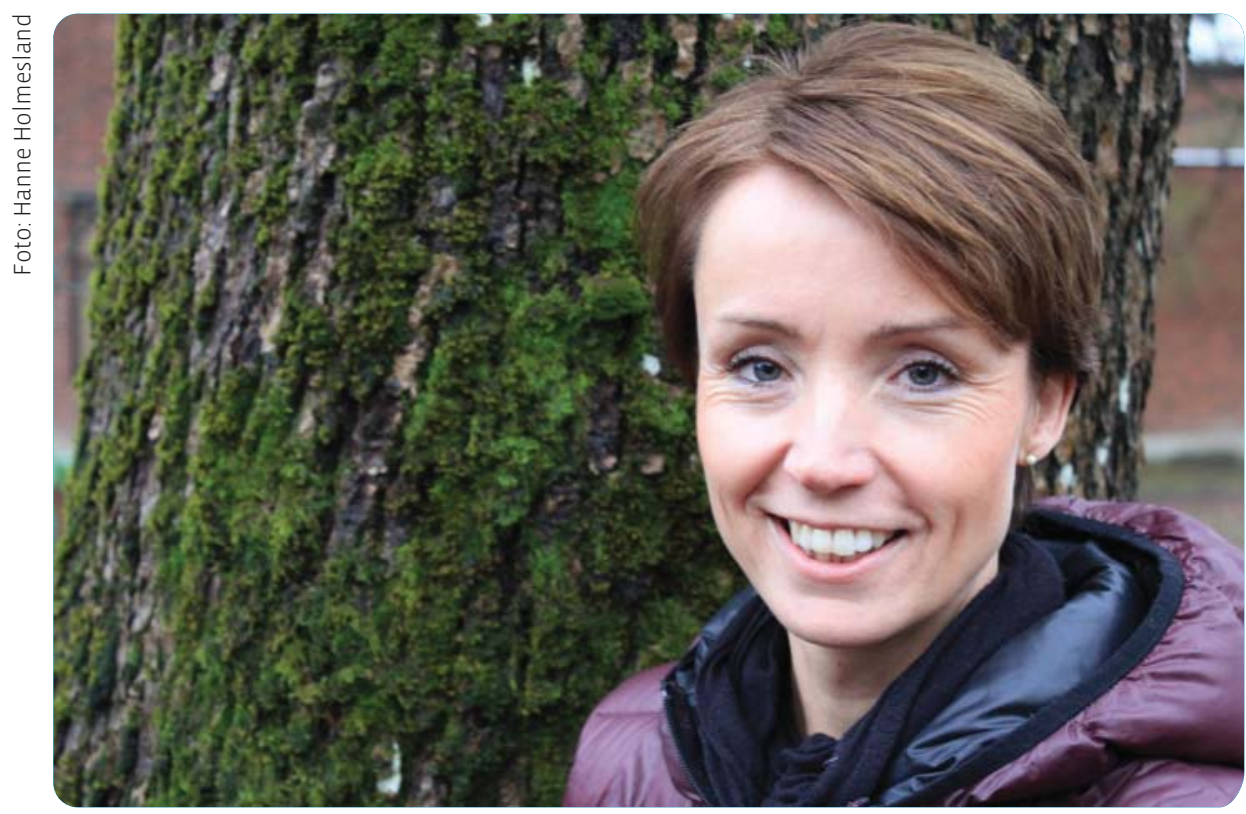

Marianne Slette Granum er mastergradsstudent og klinisk sosionom ansatt i avdeling for psykiatri og rus i Nes Kommune, Akershus, med 15 års yrkeserfaring fra førstelinjen.

Kompetanseheving i tjenesteapparatet er et sentralt selvmordsforebyggingstiltak vektlagt i Handlingsplan for forebygging av selvmord og selvskading 2014-2017. Masterprogrammet i Psykososialt arbeid - selvmord, rus, vold og traumer ved UiO henvender seg til faggrupper i kommunalt og statlig tjenesteapparat med tilbud om opplæring i selvmordsforebygging.

\section{Hva består ditt arbeid i?}

- Min arbeidshverdag består i hovedsak av samtaler med og oppfølging av enkeltpasienter med psykiske utfordringer, både av mild og mer alvorlig art. Dette innebærer også pårørendearbeid og utstrakt samarbeid med andre tjenester, både internt i kommunen og i spesialisthelsetjenesten.

Hvorfor søkte du opptak på masterprogrammet?

- Mitt utgangspunkt for å søke masterprogrammet var, foruten "sult" etter mer kunnskap, et behov for å øke kompetansen i forhold til det stadig økende antall pasienter med kompliserte og sammensatte utfordringer. Mindre kapasitet i spesialisthelsetjenesten fører til økt press på de kommunale tjenestene, og
Samhandlingsreformen vil legge ytterligligere press på kommunene, både hva gjelder innhold og utforming av tjenestene. Dette krever økt kompetanse.

Synes du undervisningen på masterprogrammet er nyttig for deg?

- Jeg hadde store forventninger til masterprogrammet, og liker spesielt vektleggingen av det psykososiale perspektivet inn mot alvorlig tematikk som suicidalitet, rus, vold og traumer.

- Første året var intenst med innføring i alle tre fagområdene. Det ga et godt og solid grunnlag for resten av studiet, med en bredere forståelse av sammenhengen og kompleksiteten i feltene.

- Jeg opplever at det er gjennomgående meget høy kvalitet på alle forelesninger, og det er et privilegium å kunne motta oppdatert kunnskap fra de fremste forskere og fagfolk på de ulike områdene.

- Studiets vektlegging av forskning og kunnskapsutvikling knyttes hele tiden tett opp mot praksisfeltet, noe som gjør det interessant og relevant i egen arbeidshverdag.
Du har valgt fordypning innen selvmordsforebyggende arbeid, har du loert noe nytt?

- Fordypningen i selvmordsforebyggende arbeid har økt min forståelse av de ulike sidene av suicidalitet. Hvordan møte pasienter i den suicidale prosessen med forebyggende intervensjoner i det kliniske arbeidet har vært særdeles nyttig i forhold til den konkrete arbeidshverdagen min. Den tverrfaglige sammensetningen av studentgruppen tilfører også verdifull kunnskap, og bidrar til økt forståelse og flere perspektiver på arbeidet.

- Jeg anbefaler masterprogrammet varmt videre, med en spesiell oppfordring til ansatte i kommunene rundt omkring om å søke. Det er i kommunene pasientene lever sine liv, og vi representerer en viktig del i behandlingskjeden og i det forebyggende arbeidet. Kommunene vil bli utfordret i de kommende årene, og masterprogrammet kan bidra til at vi er bedre rustet for utfordringene som kommer.

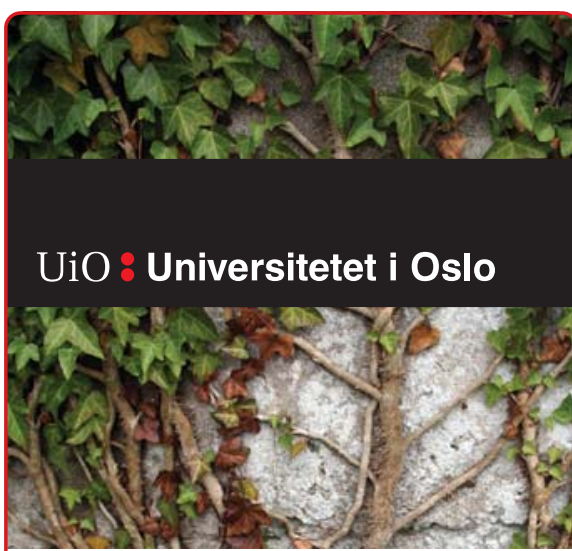

MASTERPROGRAM I

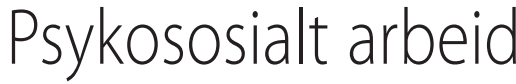
- selvmord, rus, vold og traumer

120 studiepoeng, deltid over 3 år.

Søknadsfrist: 15. april 2015.

Nærmere info:

http://www.uio.no/studier/program/ psykososial-master/ 